\title{
Effect of pre-emergent graminicide herbicides on germination and early development of native species
}

\author{
Efeito de herbicidas graminicidas pré-emergentes sobre a germinação e o \\ desenvolvimento inicial de espécies nativas
}

\begin{abstract}
Ricardo Fagundes MARQUES ${ }^{1}$; Guilherme Henrique Rodrigues PINHEIRO²; Anney Silva MARQUES; Rodrigo Marques de SOUZA ${ }^{4}$; Sidnei Roberto de MARCHI ${ }^{5}$

${ }^{1}$ Autor para correspondência: Eng. Agr., Mestrando em Produção Vegetal, Universidade Federal de Goiás, Regional Jataí, Rodovia BR-364 Setor Francisco Antônio 75801615 - Jataí, GO - Brasil, rfmarques94@gmail.com

${ }^{2}$ Eng. Agr., Mestrando em Produção Vegetal, Universidade Federal de Goiás, Regional Jataí, grhpinheiro@gmail.com

${ }^{3}$ Graduanda em Agronomia, Universidade Federal de Mato Grosso, Campus do Araguaia, anney_markes@hotmail.com

${ }^{4}$ Graduando em Agronomia, Universidade Federal de Mato Grosso, Campus do Araguaia, rodrigomarques_agro@hotmail.com

${ }^{5}$ Eng. Agr., Doutor em Agronomia, Universidade Federal de Mato Grosso, Campus do Araguaia, sidneimarchi.ufmt@gmail.com.
\end{abstract}

Recebido em: 06-09-2018; Aceito em: 13-12-2018

\begin{abstract}
The occurrence of weeds has been the main obstacle to vegetation recovery in Cerrado areas unduly occupied by agricultural and livestock activities. This study evaluates the effect of different pre-emergent herbicides on the emergence, survival, and early development of seedlings of the native species jatobá (Hymenaea stigonocarpa), urucum (Bixa orellana), dry flour (Albizia hasslerii), and white jurema (Mimosa interrupta). The experiment was carried out under greenhouse conditions in a completely randomized experimental design with five replicates, where the treatments were constituted by herbicides: isoxaflutole, applied at the doses of 100,200 , and $300 \mathrm{~g}$ ai ha $^{-1}$; pendimethalin, at 500,1000, and $4000 \mathrm{~g}_{\text {ai ha }}{ }^{-1}$; and trifluralin, at 600,1200 , and $2400 \mathrm{~g}_{\text {ai ha }}{ }^{-1}$; in addition to a control treatment, without the application of herbicides. Herbicide phytotoxicity was evaluated at 35 days after emergence for the number of emerged seedlings, number of leaves per seedling, seedling height and diameter, and root and shoot dry weight. With the results obtained, it is possible to affirm that under the conditions of the experiment, all the herbicides and doses used did not affect the emergence and early development of seedlings of species $H$. stigonocarpa and $B$. orellana. For species $A$. hasslerii, the dose of $300 \mathrm{~g}$ ai ha-1 of herbicide isoxaflutole was not selective. All doses of the herbicide trifluralin showed selectivity for species $M$. interrupta.
\end{abstract}

Additional keywords: isoxaflutole; pendimethalin; selectivity; trifluralin.

\section{Resumo}

A ocorrência de plantas daninhas tem representado a principal barreira para a recuperação da cobertura vegetal de áreas do Cerrado, indevidamente ocupadas pela exploração agropecuária. O presente trabalho teve o objetivo de avaliar o efeito de diferentes herbicidas pré-emergentes sobre a emergência, sobrevivência e desenvolvimento inicial de plântulas das espécies nativas jatobá (Hymenaea stigonocarpa), urucum (Bixa orellana), farinhaseca (Albizia hasslerii) e jurema-branca (Mimosa interrupta). O experimento foi instalado em condições de estufa agrícola, no delineamento experimental inteiramente casualizado, com cinco repetições, sendo os tratamentos constituídos pelos herbicidas: isoxaflutole aplicado nas doses de 100, 200 e $300 \mathrm{~g}^{\mathrm{ia}}$ ha $^{-1}$; pendimentalim aplicado nas doses de 500, 1.000 e $4.000 \mathrm{~g}_{\text {ia ha-1 }}^{-1}$ e pelo herbicida trifluralina aplicado nas doses de 600, $1.200 \mathrm{e}$ $2.400 \mathrm{~g}_{\text {ia }} \mathrm{ha}^{-1}$, além da testemunha, sem a aplicação de herbicidas. A fitotoxidade dos herbicidas foi avaliada aos 35 dias após a emergência, quanto ao número de plântulas emergidas, número de folhas por plântula, altura e diâmetro do coleto das plântulas e matéria seca de raiz e da parte aérea. Com os resultados obtidos, é possível afirmar, nas condições em que o experimento foi conduzido, que todos os herbicidas e as doses utilizadas não prejudicaram a emergência e o desenvolvimento inicial de plântulas das espécies $H$. stigonocarpa e $B$. orellana. Para a espécie $A$. hasslerii, a dose de $300 \mathrm{~g}^{\text {ia ha }}{ }^{-1}$ do herbicida isoxaflutole não foi seletiva. Todas as doses do herbicida trifluralina apresentaram seletividade para a espécie $M$. interrupta.

Palavras-chave adicionais: isoxaflutole; pendimentalim; seletividade; trifluralina.

\section{Introduction}

The occupation of ecosystems for agribusiness development suppressing plant growth is cause for great concern, especially regarding the occupation and deforestation of the Brazilian Cerrado (Silva et al., 2015). This expansion occurs mainly in areas of dense vegetation and flat relief, favoring the advance of 
mechanized agriculture and extensive cattle raising (Rocha et al., 2011). Approximately 53\% of the 204 million hectares of this biome are estimated to have already been altered (Beuchle et al., 2015), with an average of 54 million hectares being converted to pasture and about 21.5 million hectares transformed by agriculture (Sano et al., 2010).

After several preservation measures, societal pressure, and financial incentives to rural producers, the demand for forest restoration intensified (Borges et al., 2011). Currently, the recovery of degraded areas has been considered a priority, given the serious environmental damage caused by anthropic actions on natural ecosystems (Nunes et al., 2015). In addition, restoration of permanent preservation areas (PPAs) with conflicting land use, and the implementation or adaptation of Legal Reserve will be mandatory due to the term of the new Brazilian Forest Law and the implementation of the Rural Environmental Registry (Aguiar et al., 2016).

However, implementation of projects to recover degraded areas using native species is expensive due to the costs of production, planting, and seedling management (Farias et al., 2012). Deployment is a decisive step for the success of a forestry enterprise; among the cautions to be taken during this phase, weed control stands out (Boscardin et al., 2016). The difficulty of controlling these plants has been considered as one of the main obstacles to the successful recovery of degraded areas (Borges et al., 2011).

When the areas intended for vegetation recovery are surrounded by pastures, there is a tendency for the clearings formed between forest structures to be quickly populated by exotic grasses, thus delaying regeneration by native species (Moraes Neto et al., 2010). The use of herbicides, coupled with other methods, may represent a viable alternative for weed control in recovery areas, but it is important to emphasize that the adoption of this method is related to use restrictions by environmental agencies or state enterprises (Resende \& Leles, 2017).

Aiming to improve weed control methods in reforestation, herbicides selective for some agricultural crops have been used empirically (Araldi et al., 2015). Notwithstanding, the impacts of these herbicides on the diversity of the native plant community have been demonstrated in only a limited number of studies and therefore deserve more attention on risk assessment (Boutin et al., 2012). It should also be noted that the few articles found addressed the selectivity of herbicides applied in post-emergence of native species.

In view of the above, this work assesses the selectivity of different doses of pre-emergent herbicides isoxaflutole, pendimethalin, and trifluralin in the emergence, survival, and early development of seedlings of the native species jatobá (Hymenaea stigonocarpa Mart. Ex Hayne), urucum (Bixa orellana L.), dry flour (Albizia hasslerii (Chodat) Burr.), and white jurema (Mimosa interrupta Benth).

\section{Materials and methods}

The experimental phase of the present research was conducted under greenhouse conditions, at the following geographic coordinates: 15052'29" S and 52 ${ }^{\circ} 18^{\prime} 35^{\prime \prime}$ W. According to the Köppen classification (1948), the climate is type Aw.

Seeds of native species (Table 1) were provided by a nongovernmental organization called Instituto Socioambiental (ISA), being manually collected in forest remnants by quilombola communities, indigenous communities, and rural settlers. No germination test was performed and seeds were not scarified. Sowing was done directly on the substrate, in which ten seeds were deposited to guarantee the emergence of at least one seedling per pot. Each species was studied individually. All emerged seedlings were maintained during the experimental period, and no thinning was performed.

The soil used as substrate was collected in the arable layer of a dystrophic Red Latosol with sandy loam texture, being dried and sieved for the removal of plant remains. Soil samples were collected and analyzed in laboratory, and the chemical and physical characteristics are presented in Table 2. No correction was made for soil fertility and acidity, and the substrate was packed in $1.0 \mathrm{~kg}$ plastic pots. Irrigation was performed daily in sufficient quantity to maintain soil moisture at field capacity without consequent loss of water due to runoff. Mean minimum and maximum daily temperatures inside the greenhouse during the experiment were $18^{\circ} \mathrm{C}$ and $35^{\circ} \mathrm{C}$, respectively.

Table 1 - Relation of the native species and weight estimation of 1,000 seeds.

\begin{tabular}{lllc}
\hline Specie & \multicolumn{1}{c}{ Family } & \multicolumn{1}{c}{ Name } & 1,000 seeds $(\mathrm{g})$ \\
\hline H. stigonocarpa & Caesalpinaceae & Jatobá do Cerrado & 3125 \\
B. orellana & Bixaceae & Urucum & 23.3 \\
A. hasslerii & Mimosaceae & Dry Flour & 27.8 \\
M. interrupta & Mimosaceae & White Jurema & 45.5 \\
\hline
\end{tabular}

Table 2 - Chemical and granulometric characterization of the soil.

\begin{tabular}{|c|c|c|c|c|c|c|c|}
\hline $\begin{array}{c}\mathrm{pH} \\
\mathrm{CaCl}_{2}\end{array}$ & $\begin{array}{l}\text { P-resin } \\
\left(\mathrm{mg} \mathrm{dm}^{-3}\right)\end{array}$ & $\mathrm{K}$ & $\mathrm{Ca}$ & $\begin{array}{l}\mathrm{Mg} \\
\left.n^{-3}\right)-\end{array}$ & $\mathrm{Al}+\mathrm{H}$ & \multirow{2}{*}{$\begin{array}{c}\mathrm{V} \\
(\%) \\
44.6 \\
\end{array}$} & \multirow{2}{*}{$\begin{array}{c}\text { M.O } \\
\left(\mathrm{g} \mathrm{dm}^{-3}\right) \\
22.0\end{array}$} \\
\hline 4.8 & 4.0 & 3.1 & 18.0 & 6.0 & 34.0 & & \\
\hline & $\begin{array}{l}\text { Sand } \\
706\end{array}$ & & & ry (g & & & \\
\hline
\end{tabular}


A completely randomized experimental design was used, with five replicates, where each pot was considered an experimental unit. Experimental treatments consisted of the herbicide isoxaflutole, applied at 100,200 , and $300 \mathrm{~g}$ ai ha ${ }^{-1}$; herbicide pendimethalin, at 500,1000 , and $4000 \mathrm{~g}$ ai $\mathrm{ha}^{-1}$; and herbicide trifluralin, applied at 600, 1200, and $2400 \mathrm{~g}$ ai ha- ${ }^{-1}$; in addition to a control treatment, without the application of herbicides. Herbicide doses considered the minimum dose, and two, three (in the case of isoxaflutole), and four times (in the case of trifluralin and pendimethalin) the average dose recommended for the various crops according to the package inserts supplied by the respective manufacturers.

Herbicide treatments were applied in preemergence with the aid of a $\mathrm{CO}_{2}$-pressurized sprayer equipped with a spray bar with four 110015 VS flat-fan nozzles, spaced $50 \mathrm{~cm}$ apart, $50 \mathrm{~cm}$ away from the target, and calibrated at $35 \mathrm{psi}$, with syrup consumption equivalent to $200 \mathrm{~L} \mathrm{ha}^{-1}$.

Seed emergence was evaluated daily until seedling emergence ceased, which corresponded to the experimental period of 35 days. Seedlings were evaluated at the end of the experimental period for the number of emerged seedlings, number of leaves per seedling, and seedling height and stem diameter at soil level.
Seedling shoots were cut and all material obtained was packed in paper bags. Next, the roots were carefully separated from the soil with the aid of water jets, and the entire root system also packed in paper bags. Shoot and root samples were maintained in a greenhouse with forced air circulation and constant temperature of $65^{\circ} \mathrm{C}$ for 72 hours, after which total dry weight was obtained with the aid of a scale with an accuracy of $0.001 \mathrm{~g}$. Subsequently, mean root and shoot dry weight were calculated as a function of the number of seedlings evaluated.

The values obtained for all variables were subjected to analysis of variance by the $F$ test using the statistical program AgroEstat (Barbosa \& Maldonado Jr., 2015). The means of treatments were compared by the Scott-Knott test at $5 \%$ probability $(p>0.05)$.

\section{Results and discussion}

All the herbicides studied did not affect the number of seedlings, number of leaves, seedling height, stem diameter, and root and shoot dry weight, regardless of the dose used. All values obtained for these variables were statistically similar $(p>0.05)$ to the values obtained in the control (Table 3 ).

Table 3 - Effect of herbicides and doses on the number of seedlings, number of leaves, height of seedlings $(\mathrm{cm})$, stem diameter $(\mathrm{mm})$ and root and shoot dry mass $(\mathrm{g})$ of $H$. stigonocarpa.

\begin{tabular}{lcccccc}
\hline \multirow{2}{*}{ Treatment } & \multicolumn{2}{c}{ Number } & Height & Diameter & \multicolumn{2}{c}{ Dry mass $(\mathrm{g})$} \\
\cline { 2 - 3 }$(\mathrm{cm})$ & Seedlings & Leaves & $(\mathrm{mm})$ & Root & Shoot \\
\hline Isoxaflutole 100 & 1.8 & 6.5 & 25.1 & 0.33 & 1.32 & 2.39 \\
Isoxaflutole 200 & 2.2 & 6.1 & 23.2 & 0.33 & 1.57 & 2.33 \\
Isoxaflutole 300 & 2.0 & 7.1 & 24.2 & 0.31 & 1.67 & 2.44 \\
Pendimentalim 500 & 2.2 & 7.1 & 22.5 & 0.33 & 1.45 & 2.51 \\
Pendimentalim 1000 & 2.2 & 5.3 & 21.3 & 0.37 & 1.76 & 2.38 \\
Pendimentalim 4000 & 1.6 & 5.5 & 21.4 & 0.32 & 1.71 & 2.31 \\
Trifluralina 600 & 1.2 & 7.2 & 21.3 & 0.34 & 1.65 & 2.41 \\
Trifluralina 1200 & 2.0 & 5.8 & 23.3 & 0.38 & 1.57 & 2.57 \\
Trifluralina 2400 & 1.6 & 6.2 & 22.7 & 0.34 & 1.55 & 2.39 \\
Control & 1.4 & 7.4 & 26.7 & 0.37 & 1.42 & 2.46 \\
\hline F Treatments & $1.89^{\text {NS }}$ & $1.27^{\text {NS }}$ & $1.69^{\text {NS }}$ & $1.71^{\text {NS }}$ & $1.41^{\text {NS }}$ & $0.38^{\text {NS }}$ \\
C.V. (\%) & 21.13 & 23.2 & 13.1 & 12.2 & 16.5 & 12.1 \\
\hline
\end{tabular}

NS - Not significant by Scott-Knott test $(p<0.05)$.

Doust et al. (2006) report that seed size is an important factor affecting the establishment of native species in forest recovery areas, where species with larger seeds have a higher establishment rate when compared to those with smaller seeds. It is noteworthy that the $H$. stigonocarpa seeds used in this experiment have a relatively high weight when compared to the other species (Table 1). Thus, it is deduced that there is more energy to feed their embryos. Supposedly because of this, the species was shown to be tolerant to all doses of the herbicides used, not showing differences in the early development when compared to the control.

Furthermore, seeds of the genus Hymenea present strong dormancy caused by tegument impermeability, especially attributed to the layer of palisade cells, which guarantees greater seed longevity, allowing seeds to germinate even after long periods of dispersion and under adverse conditions (Freitas et al., 2013). Therefore, it is possible to infer that all preemergent herbicides applied did not affect the viability of $H$. stigonocarpa seeds due to these characteristics of impermeable tegument and strong resistance, which conferred normal emergence for the species.

When evaluating the selectivity of glyphosate and sulfentrazone in $H$. courbaril seedlings, Gandini et al. (2014) confirmed that these herbicides have high potential to be used to control weeds in planting areas 
of this species at an early stage of development. The doses applied by the authors did not significantly affect the variables height, diameter, and root and shoot dry weight, showing no difference with the control. This corroborates the results of this research, where herbicides isoxaflutole, pendimethalin, and trifluralin also did not affect such parameters.

It should be noted that the selectivity of herbicides in native species is related to the absence of differences between treatments with and without the use of these products. Thus, it can be stated that all doses of the herbicides used in this research were selective for species $H$. stigonocarpa. Corroborating these results, Machado et al. (2013) comment that the absence of decreased seedling development in Bowdichia virgilioides, Kielmeyera lathrophyton, and Plathymenia reticulata are indications that these species are tolerant to glyphosate. According to Agostinetto et al. (2010), herbicide isoxaflutole was selective for eucalyptus genotypes because, regard- less of the dose, it presented low phytotoxicity and there were no differences for the variables height, dry weight, and diameter when compared to the treatment without herbicide application.

Similar results were obtained when the herbicides were applied in the pre-emergence of $B$. orellana, since the number of leaves, seedling height, neck diameter, and root and shoot dry weight did not differ statistically from the control (Table 4).

Nonetheless, it is important to note that the herbicide treatments isoxaflutole at $200 \mathrm{~g}$ ai ha- ${ }^{-1}$ and trifluralin at 600 and $1200 \mathrm{~g}$ ai ha-1 ${ }^{-1}$ provided a mean number of emerged seedlings statistically higher $(p<0.05)$ than that found in the control, indicating a possible stimulant effect for the products used since seeds were not scarified, as recommended by Campos Filho (2009). In general, the number of seedlings for these treatments was approximately four emerged seedlings, whereas in the control the average number was less than three emerged seedlings (Table 4).

Table 4 - Effect of herbicides and doses on the number of seedlings, number of leaves, height of seedlings $(\mathrm{cm})$, stem diameter $(\mathrm{mm})$ and root and shoot dry mass $(\mathrm{g})$ of $B$. orellana.

\begin{tabular}{lcccccc}
\hline \multirow{2}{*}{ Treatment } & \multicolumn{2}{c}{ Number } & Height & Diameter & \multicolumn{2}{c}{ Dry mass $(\mathrm{g})$} \\
\cline { 2 - 3 } & Seedlings & Leaves & $(\mathrm{cm})$ & $(\mathrm{mm})$ & Root & Shoot \\
\hline Isoxaflutole 100 & $2.4 \mathrm{~b}$ & 6.0 & 7.50 & 0.11 & 0.48 & 0.23 \\
Isoxaflutole 200 & $4.0 \mathrm{a}$ & 5.8 & 7.28 & 0.11 & 0.43 & 0.20 \\
Isoxaflutole 300 & $3.0 \mathrm{~b}$ & 4.6 & 6.74 & 0.10 & 0.42 & 0.21 \\
Pendimentalim 500 & $3.0 \mathrm{~b}$ & 5.2 & 8.03 & 0.10 & 0.45 & 0.26 \\
Pendimentalim 1000 & $3.0 \mathrm{~b}$ & 5.9 & 7.17 & 0.11 & 0.41 & 0.24 \\
Pendimentalim 4000 & $2.4 \mathrm{~b}$ & 6.3 & 7.62 & 0.10 & 0.42 & 0.22 \\
Trifluralina 600 & $3.6 \mathrm{a}$ & 6.0 & 7.87 & 0.10 & 0.42 & 0.22 \\
Trifluralina 1200 & $3.4 \mathrm{a}$ & 6.0 & 7.71 & 0.12 & 0.41 & 0.22 \\
Trifluralina 2400 & $2.4 \mathrm{~b}$ & 5.8 & 7.50 & 0.11 & 0.43 & 0.25 \\
Control & $2.4 \mathrm{~b}$ & 5.6 & 6.74 & 0.09 & 0.48 & 0.23 \\
\hline F Treatments & $2.60^{*}$ & $1.16^{\text {NS }}$ & $0.75^{\text {NS }}$ & $0.98^{\text {NS }}$ & $1.73^{\text {NS }}$ & $1.60^{\text {NS }}$ \\
CV (\%) & 26.8 & 18.2 & 15.4 & 14.0 & 9.9 & 12.6 \\
\hline
\end{tabular}

NS - not significant $(p>0.05)$ by $F$ test; ${ }^{*}$ significant $(p<0.05)$ by $F$ test. Means followed by the same letter in the column do not differ by Scott-Knott test $(p>0.05)$.

Araújo Neto et al. (2018) commented that, given the low germination percentage of $B$. orellana seeds due to the dormancy imposed by impermeable tegument, treatments with stimulants to break dormancy are necessary for the production of seedlings of this species. It is assumed that herbicides isoxaflutole, at $200 \mathrm{~g}$ ai ha ${ }^{-1}$, and trifluralin, at 600 and $1200 \mathrm{~g}$ ai ha ${ }^{1}$, may have broken seed dormancy, since the results found in this research show that these treatments were superior to the control, but the possible causes of the event are unknown.

When using herbicide setoxidim at doses of 184, 368, and $736 \mathrm{~g}$ ai ha-1 on Guazuma ulmifolia and Senna multijuga, Brancalion et al. (2009) also found effects similar to those of this study. The authors comment that herbicide setoxidim was even favorable to the growth of $S$. multijuga and $G$. ulmifolia, indicating a potential stimulant effect of setoxidim. Research by Pereira et al. (2015) demonstrated that different doses of the herbicide glyphosate did not cause toxicity in the native tree species Cyntharexyllum myrianthum and Psidium cattleyanum. The authors emphasize that some doses actually provided greater increases in several parameters evaluated when compared to the control, without herbicide application.

The results presented in Table 5 refer to the effects of herbicides isoxaflutole, pendimethalin, and trifluralin, applied at different doses in the pre-emergence of $A$. hasslerii. It should be noted that herbicide isoxaflutole, at $300 \mathrm{~g}$ ai ha-1, was the only treatment that negatively affected all the variables evaluated for this species, since the mean values differ statistically $(P<0.05)$ from the values obtained in the control. Moreover, no significant differences $(p>0.05)$ were observed in these variables for the other doses of isoxaflutole (100 and $200 \mathrm{~g}$ ai ha ${ }^{-1}$ ), and for herbicides pendimethalin, at $500 \mathrm{~g}$ ai ha-1, and trifluralin, at $600 \mathrm{~g}$ ai ha ${ }^{-1}$, when compared to the control. 
Table 5 - Effect of herbicides and doses on the number of seedlings, number of leaves, height of seedlings (cm), stem diameter $(\mathrm{mm})$ and root and shoot dry mass $(\mathrm{g})$ of $A$. hasslerii.

\begin{tabular}{lcccccc}
\hline \multirow{2}{*}{ Tratamento } & \multicolumn{2}{c}{ Number } & Height & Diameter & \multicolumn{2}{c}{ Dry mass $(\mathrm{g})$} \\
\cline { 2 - 3 } & Seedlings & Leaves & $(\mathrm{cm})$ & $(\mathrm{mm})$ & Root & Shoot \\
\hline Isoxaflutole 100 & $4.2 \mathrm{~b}$ & $6.2 \mathrm{a}$ & $5.10 \mathrm{a}$ & $0.06 \mathrm{a}$ & $0.03 \mathrm{~b}$ & $0.03 \mathrm{a}$ \\
Isoxaflutole 200 & $4.0 \mathrm{~b}$ & $6.1 \mathrm{a}$ & $4.63 \mathrm{a}$ & $0.07 \mathrm{a}$ & $0.03 \mathrm{~b}$ & $0.03 \mathrm{a}$ \\
Isoxaflutole 300 & $1.0 \mathrm{C}$ & $1.1 \mathrm{~b}$ & $1.96 \mathrm{~b}$ & $0.03 \mathrm{~b}$ & $0.01 \mathrm{c}$ & $0.01 \mathrm{~b}$ \\
Pendimentalim 500 & $4.1 \mathrm{~b}$ & $6.2 \mathrm{a}$ & $5.60 \mathrm{a}$ & $0.09 \mathrm{a}$ & $0.03 \mathrm{~b}$ & $0.03 \mathrm{a}$ \\
Pendimentalim 1000 & $4.6 \mathrm{~b}$ & $6.3 \mathrm{a}$ & $5.68 \mathrm{a}$ & $0.08 \mathrm{a}$ & $0.06 \mathrm{a}$ & $0.04 \mathrm{a}$ \\
Pendimentalim 4000 & $6.2 \mathrm{a}$ & $6.6 \mathrm{a}$ & $5.43 \mathrm{a}$ & $0.09 \mathrm{a}$ & $0.03 \mathrm{~b}$ & $0.04 \mathrm{a}$ \\
Trifluralina 600 & $4.4 \mathrm{~b}$ & $6.4 \mathrm{a}$ & $5.88 \mathrm{a}$ & $0.08 \mathrm{a}$ & $0.03 \mathrm{~b}$ & $0.05 \mathrm{a}$ \\
Trifluralina 1200 & $5.2 \mathrm{a}$ & $7.3 \mathrm{a}$ & $5.43 \mathrm{a}$ & $0.08 \mathrm{a}$ & $0.03 \mathrm{~b}$ & $0.04 \mathrm{a}$ \\
Trifluralina 2400 & $6.2 \mathrm{a}$ & $6.0 \mathrm{a}$ & $5.22 \mathrm{a}$ & $0.07 \mathrm{a}$ & $0.03 \mathrm{~b}$ & $0.03 \mathrm{a}$ \\
Control & $4.4 \mathrm{~b}$ & $6.7 \mathrm{a}$ & $5.85 \mathrm{a}$ & $0.07 \mathrm{a}$ & $0.03 \mathrm{~b}$ & $0.04 \mathrm{a}$ \\
\hline F Treatments & $11.16^{* *}$ & $16.9^{\star *}$ & $5.05^{\star *}$ & $7.57^{\star *}$ & $17.00^{* *}$ & $8.34^{\star *}$ \\
CV (\%) & 21.9 & 15.8 & 22.7 & 20.9 & 24.6 & 24.2 \\
\hline
\end{tabular}

${ }^{* *}$ significant $(p<0.01)$ by $F$ test. Means followed by the same letter in the column do not differ by Scott-Knott test $(p>0.05)$.

Soto Gonzales et al. (2010) commented that, due to the low seed viability of $A$. hasslerii, the germination of this species can be influenced by several factors, including temperature changes, which can also affect dry weight. This low viability and resistance of seeds may be related to the highest dose of herbicide isoxaflutole leading to the lowest emergence rate of this species in this study. In the research by Brighenti \& Muller (2014), the authors observed that herbicide isoxaflutole was the most phytotoxic herbicide for Khaya ivorensis and Toona ciliata, where all the variables evaluated presented a statistical difference to the control and the phytotoxicity levels were higher than those of other herbicides.

Silva et al. (2014) add that products applied in the pre-emergence of weeds, such as isoxaflutole, reach the soil directly and may cause greater damage by increasing the risk of exposure of soil phosphatesolubilizing microorganisms. The authors also noted that the application of isoxaflutole reduces root colonization of eucalyptus seedlings by arbuscular mycorrhizal fungi, also decreasing the potential for inorganic phosphate solubilization, directly affecting the early growth of the species. This fact corroborates the results obtained in this research, since the highest dose of the herbicide isoxaflutole directly affected the early development of $A$. hasslerii seedlings.

Polini et al. (2018) evaluated the selectivity of herbicides in native forest species of the Cerrado biome and concluded that herbicide imazapyr, when applied at low doses in post-emergence, is selective for tree species Schinus terebinthifolia, Peltophorum dubium, and Handroanthus albus; at high concentrations, however, it may affect their survival differently. Tavares et al. (2017) observed that the initial growth of Caryocar brasiliense plants was benefited from the application of 2,4-D subdoses for the variables leaf area, specific leaf area, and leaf area ratio. However, with increasing doses, there was a reduction in seedling growth, characterized by a decrease in leaf variables and in the total dry weight of plants. These results are similar to those found in this research, where herbicide isoxaflutole was selective at lower doses, but impaired the growth and development of $A$. hasslerii at the highest dose.

However, it is important to emphasize that the treatment with $1000 \mathrm{~g}$ ai ha- ${ }^{-1}$ pendimethalin gave a statistically higher mean root dry weight $(p<0.05)$ compared to that found in the control. Moreover, pendimethalin at $4000 \mathrm{~g}$ ai ha- ${ }^{-1}$ and trifluralin at 1200 and $2400 \mathrm{~g}$ ai ha ${ }^{-1}$ were statistically different $(p<0.05)$ for the number of emerged seedlings, with higher averages than those found in the control, indicating a possible stimulating effect of the products at these doses (Table 5).

When evaluating the use of forest species to reduce the clomazone residue in the environment, Cabral et al. (2017) found results similar to those of this study, in which the root dry weight of species Jacaranda puberla, Inga marginata, Caesalpinia ferrea, Cedrela fissilis, and Schinopsis brasiliensis showed an average increase of $29.6 \%$ with herbicide application. Fiore et al. (2016), studying seedlings of $J$. puberla and Inga marginata, found a significant average increase of root dry weight with herbicide application (25\% increase when herbicide atrazine was applied, and $18 \%$ increase when herbicide 2,4-D was applied).

For herbicide trifluralin at doses of 600,1200 , and $2400 \mathrm{~g}$ ai ha-1 applied to M. interrupta, no statistical differences $(p>0.05)$ were observed for the number of seedlings, number of leaves, neck diameter, and root and shoot dry weight in relation to the control. However, the treatments with isoxaflutole and pendimethalin negatively influenced all variables evaluated, since the means were lower than the control, regardless of the dose used (Table 6).

Herbicide trifluralin, used at low concentrations, did not interfere with the initial growth of the pioneer species Croton urucana and Muntingia calabura (Moraes Neto et al., 2010). Jatropha curcas plants show high sensitivity to the herbicide isoxaflutole, since the doses of the product caused severe plant damage, negatively influencing all evaluated variables (Rocha et al., 2010; Inoue et al., 2014). These results are similar 
to those found in this research using species $M$. interrupta, where herbicide trifluralin did not affect the variables evaluated in relation to the control; herbicide isoxaflutole, in turn, damaged the seedlings of the species, regardless of the dose.

Table 6 - Effect of herbicides and doses on the number of seedlings, number of leaves, height of seedlings $(\mathrm{cm})$, stem diameter $(\mathrm{mm})$ and root and shoot dry mass $(\mathrm{g})$ of $M$. interrupta.

\begin{tabular}{|c|c|c|c|c|c|c|}
\hline \multirow{2}{*}{ Treatment } & \multicolumn{2}{|c|}{ Number } & \multirow{2}{*}{$\begin{array}{l}\text { Height } 11 \\
(\mathrm{~cm})\end{array}$} & \multirow{2}{*}{$\begin{array}{l}\text { Diameter } 11 \\
(\mathrm{~mm})\end{array}$} & \multicolumn{2}{|c|}{ Dry mass $(\mathrm{g})^{\lfloor! 1}$} \\
\hline & Seedlings 11 & Leaves ${ }^{1}$ & & & Root & Shoot \\
\hline Isoxaflutole 100 & $1.48 \mathrm{c}$ & $2.09 \mathrm{~b}$ & $2.66 \mathrm{~b}$ & $1.04 \mathrm{~b}$ & $1.06 \mathrm{~b}$ & $1.03 \mathrm{~b}$ \\
\hline Isoxaflutole 200 & $1.08 \mathrm{~d}$ & $1.25 \mathrm{c}$ & $1.60 \mathrm{c}$ & $1.02 b$ & $1.05 b$ & $1.01 \mathrm{c}$ \\
\hline Isoxaflutole 300 & $1.08 \mathrm{~d}$ & $1.20 \mathrm{c}$ & $1.46 \mathrm{c}$ & $1.02 b$ & $1.00 \mathrm{c}$ & $1.01 \mathrm{c}$ \\
\hline Pendimentalim 500 & $1.39 \mathrm{c}$ & $2.14 b$ & $1.67 \mathrm{c}$ & $1.04 b$ & $1.06 \mathrm{~b}$ & $1.03 \mathrm{~b}$ \\
\hline Pendimentalim 1000 & $1.08 \mathrm{~d}$ & $1.29 \mathrm{c}$ & $1.44 \mathrm{c}$ & $1.02 b$ & $1.03 \mathrm{c}$ & $1.01 \mathrm{c}$ \\
\hline Pendimentalim 4000 & $1.25 \mathrm{~d}$ & $1.89 \mathrm{~b}$ & $1.47 \mathrm{c}$ & $1.01 \mathrm{~b}$ & $1.02 \mathrm{c}$ & $1.01 \mathrm{C}$ \\
\hline Trifluralina 600 & $2.18 \mathrm{a}$ & $2.52 \mathrm{a}$ & $3.25 \mathrm{a}$ & $1.09 \mathrm{a}$ & $1.09 \mathrm{a}$ & $1.06 \mathrm{a}$ \\
\hline Trifluralina 1200 & $1.22 \mathrm{a}$ & $2.35 \mathrm{a}$ & $3.18 \mathrm{~b}$ & $1.10 \mathrm{a}$ & $1.10 \mathrm{a}$ & $1.05 \mathrm{a}$ \\
\hline Trifluralina 2400 & $1.26 \mathrm{a}$ & $2.23 \mathrm{a}$ & $3.16 \mathrm{~b}$ & $1.10 \mathrm{a}$ & $1.12 \mathrm{a}$ & $1.06 \mathrm{a}$ \\
\hline Control & $2.29 \mathrm{a}$ & $2.47 \mathrm{a}$ & $3.42 \mathrm{a}$ & $1.07 \mathrm{a}$ & $1.08 \mathrm{a}$ & $1.06 \mathrm{a}$ \\
\hline F Treatments & $22.49^{* \star}$ & $10.04^{* *}$ & $46.03^{\star *}$ & $8.31^{\star \star}$ & $5.19^{\star \star}$ & $7.89^{* \star}$ \\
\hline CV $(\%)$ & 12.7 & 18.3 & 11.7 & 2.9 & 5.1 & 2.1 \\
\hline
\end{tabular}

${ }^{1}$ Means transformed by square root $x+1 ;{ }^{* *}$ significant $(p<0.01)$ by $\mathrm{F}$ test. Means followed by the same letter in the column do not differ by Scott-Knott test $(p>0.05)$.

It is highlighted that the herbicides acted differently, depending on the dose and mainly on the evaluated species. According to Duarte et al. (2006), the lower sensitivity of native species to herbicides may be related to the rate of absorption and metabolization of the active ingredient of the product; the higher this rate, the more harmful the herbicide action in the plant. Corroborating the results of this research, Monquero et al. (2011) state that the different concentrations of herbicides imazapyr, sulfentrazone, glyphosate, and metribuzin affected the survival of Acacia polyphylla, Enterolobium contortisiliquum, Ceiba speciosa, and Luehea divaricata differently.

The identification of Cerrado native plant species that can act as bioindicators of the action of herbicides, that is, that demonstrate sensitivity to herbicides, can assist in monitoring the impacts of the different products in the remaining areas of this biome (Batista et al., 2018). According to the results obtained in this research, it can be inferred that isoxaflutole, at the dose of $100 \mathrm{~g}$ ai ha ${ }^{-1}$; pendimethalin, at $500 \mathrm{~g}$ ai ha-1; and trifluralin, at $600 \mathrm{~g}^{\text {ai }} \mathrm{ha}^{-1}$, if used with discretion and respecting the current legislation, present potential of use in vegetation recovery. Their use in intercropping with native species $H$. stigonocarpa, $B$. orellana, $A$. hasslerii, and $M$. interrupta represents an efficient alternative for the management of exotic grasses.

\section{Conclusions}

All herbicides and doses used did not affect the emergence and early development of seedlings of species $H$. stigonocarpa and $B$. orellana. For species $A$. hasslerii, only the dose of $300 \mathrm{~g}$ ai ha ${ }^{-1}$ of herbicide isoxaflutole was not selective. All doses of herbicide trifluralin showed selectivity for species $M$. interrupta.

\section{References}

Agostinetto D, Peligrinotti Tarouco C, Markus C, Oliveira E, Betemps Vaz da Silva JM, Tironi SP (2010) Seletividade de genótipos de eucalipto a doses de herbicidas. Semina: Ciências Agrárias 31(3):585-598.

Aguiar LM, Santos JB, Costa VA, Brito LA, Ferreira EA, Pereira I.M, Aspiazu I (2016) Herbicide tolerance and water use effciency in forest species used in degraded áreas recovery programs. Bosque 37(3):493-500.

Araldi R, Corniani N, Tropaldi L, Girotto M, Belapart D, Simões PS, Velini, ED (2015) Chlorophyll fluorescence in guanandi tree (Calophyllum brasiliense) after herbicide application. Planta Daninha 33(1)77-82.

Araújo Neto AC, Santos OO, Ferreira DM, Nunes RTC, Públio APPB, Amaral CLF (2018) Germination and vigor of Bixa orellana I. seeds pre-soaked in a plant biostimulant. Floresta 48(3):293-302.

Barbosa JC, Maldonado Jr. W. (2015) Experimentação agronômica \& AgroEstat: Sistemas para análises estatísticas e ensaios agronômicos, Gráfica Multipress Ltda, Jaboticabal, p 396.

Batista PF, Costa AC, Megguer CA, Lima JS, Silva FB, Guimarães DS, Almeida GM, Nascimento KJT (2018) Pouteria torta: a native species of the Brazilian Cerrado as a bioindicator of glyphosate action. Brazilian Journal of Biology 78(2):296-305.

Beuchle R, Grecchi RC, SHimabukuro YE, Seliger R, Eva HD, Sano E, Achard F (2015) Land cover changes in the Brazilian Cerrado and Caatinga biomes from 1990 to 2010 based on a systematic remote sensing sampling approach. Applied Geography 58:116-127. 
Borges LAC, Rezende JLP, Pereira JAA, Coelho Junior LM, Barros DA (2011) Áreas de preservação permanente na legislação ambiental brasileira. Ciência Rural 41(7):1202-1210.

Boscardin J, Costa EC, Garlet J, Machado LM, Machado DN, Pedron L, Bolzan LC (2016). Efeitos de diferentes tipos de controle de plantas infestantes sobre a Mirmecofauna em Eucalyptus grandis. Ciência Florestal 26(1):21-34.

Boutin C, Aya KL, Carpenter D, Thomas PJ, Rowland $O$ (2012) Phytotoxicity testing for herbicide regulation: shortcomings in relation to biodiversity and ecosystem services in agrarian systems. Science of the Total Environment 415:79-92.

Brancalion PHS, Isernhagen I, Machado RP, Christoffoleti PJ, Rodrigues RR (2009) Seletividade dos herbicidas setoxidim isoxaflutol e bentazona espécies arbóreas nativas. Pesquisa Agropecuária Brasileira 44(3):251-257.

Brighenti AM, Muller MD (2014) Tolerância de plantas de Khaya ivorensis e Toona ciliata a herbicidas. Floresta 44(4):747-754.

Cabral CM, Santos JB, Ferreira EA, Machado VM, Pereira IM, Silva DV, Souza MF (2017) Tolerance to the herbicide clomazone and potential for changes of forest species. Bioscience Journal 33(4):897-904.

Campos Filho EM (2009) Plante as árvores do Xingu e Araguaia: Vol. III - Guia de identificação. São Paulo: Instituto Socioambiental. 297p.

Doust SJ, Erskine PD, Lamb D (2006) Direct seeding to restore rain forest species: microsite effects on the early establishment and growth of rainforest tree seedlings on degraded land in the wet tropics of Australia. Forest Ecology and Management 234(1-3):333-343.

Duarte NF, Karan DSN, Cruz MB, Scotti MRM (2006) Seletividade de herbicidas sobre Myracrodruon urundeuva (aroeira). Planta Daninha 24(2):329-337.

Farias CCM, Rondon Neto RM, Yamashita OM, Farias CBM (2012) Efeitos de subdoses de glyphosate em plantas jovens de seringueira (Hevea brasiliensis Aubl). Revista Brasileira de Herbicidas 11(1):119-125.

Fiore RA, Santos JB, Ferreira EA, Cabral CM, Pereira IM (2016) Growth and nutritional analysis of tree species in contaminated substrate by leachable herbicides. Revista Árvore 40(4):585-594.

Freitas A R, Lopes JC, Matheus MT, Mengarda LHG, Venancio LP, Caldeira MVW (2013) Superação da dormência de sementes de jatobá. Pesquisa Florestal Brasileira 33(73):85-89.
Gandini EMM, Santos JB, Gandini AMM, Santanna RC, Silva DV (2014) Selectivity of Herbicide and Rhizospheric Microbial Activity on Hymenaea corbaril L Seedlings. Communications in soil science and plant analysis 45(17):2235-2246.

Inoue $\mathrm{MH}$, Pereira KM, Mendes KF, Santos EG, Dallacort R, Possamai ACS (2014) Seletividade de herbicidas para pinhão manso em condições de casa de vegetação e campo Bioscience Journal 30(5):791801.

Köppen W (1948) Climatología Gráfica Panamericana Buenos Aires Argentina.

Machado VM, Santos JB, Pereira IM, Lara RO, Cabral CM, Amaral CS (2013) Sensibilidade de mudas de espécies florestais nativas ao glyphosate. Bioscience Journal 29(6):1941-1951.

Monquero PA, Penha AS, Orzari I, Hirata ACS (2011) Seletividade de herbicidas a mudas das espécies nativas Acacia polyphylla Enterolobium contortisiliquum (Fabaceae) Ceiba speciosa e Luehea divaricata (Malvaceae). Planta Daninha 29(1):1-10.

Moraes Neto SP, Poggiani F, Rodrigues RR, Christoffoleti PJ (2010) Efeito do controle de gramíneas no crescimento de quatro espécies arbóreas no fragmento de floresta secundária. Embrapa CerradosBoletim de Pesquisa e Desenvolvimento 289:23 p.

Nunes YRF, Fagundes NCA, Veloso MDM, Gonzaga APD, Domingues EBS, Almeida HS, Castro GC, Santos RB (2015) Sobrevivência e crescimento de sete espécies arbóreas nativas em uma área degradada de floresta estacional decidual norte de Minas Gerais. Revista Árvore 39(5):801-810.

Pereira MRR, Souza GSF, Fonseca ED, Martins D (2015) Subdoses de glyphosate no desenvolvimento de espécies arbóreas nativas. Bioscience Journal 31(2):326-332.

Polini DMSS, Mendoça CG, Teodoro PE (2018) Selectivity of herbicides in native forest species of Cerrado. Bioscience Journal 34(2):326-332.

Resende AS, Leles PSS (2017) Controle de plantas daninhas em restauração florestal. Brasília-Embrapa Agrobiologia: $107 \mathrm{p}$.

Rocha GF, Ferreira LG, Ferreira NC, Ferreira ME (2011) Detecção de desmatamentos no bioma cerrado entre 2002 e 2009: Padrões, tendências e impactos. Revista Brasileira de Cartografia 63(3):341-349.

Rocha PRR, Silva AF, Faria AT, Galon L, Ferreira EA, Felipe RS, Silva AA, Dias LAS (2010) Seletividade de herbicidas pré-emergentes ao pinhão-manso (Jatropha curcas). Planta Daninha 28(4):801-806. 
Sano EE, Rosa R, Brito JLS, Ferreira LG (2010) Land cover mapping of the tropical savana region in Brazil. Environmental Monitoring and Assessment (Print) 166(1-4):113-124.

Silva GS, Melo CAD, Fialho CMT, Santos LDT, Costa MD, Silva AA (2014) Impacto de sulfentrazona isoxaflutol e oxyfluorfem sobre a microbiota de dois solos florestais. Bragantia 73(3):292-299.

Silva JBL, Sousa PA, Souza KB, Almeida KNS, Pires LC (2015) Evolução temporal do desmatamento na bacia do riacho da Estiva Piauí. Revista Engenharia na Agricultura 23(4):363-370.
Soto Gonzales JL, Valiengo Valeri S, Paula RC (2010) Germinación de semillas de Albizia hassleri a diferentes temperaturas, en condiciones de laboratorio. Bosque 31(1): 39-44.

Tavares CJ, Pereira LS, Araújo ACF, Martins DA, Jakelaitis A (2017) Crescimento inicial de plantas de pequi após aplicação de 2, 4-D. Pesquisa Florestal Brasileira 37(89):81-87. 